\title{
PENYELESAIAN SENGKETA PAJAK
}

\author{
Hanggoro Pamungkas \\ Jurusan Akuntansi, Fakultas Ekonomi dan Bisnis, Bina Nusantara University \\ Jln. K.H. Syahdan No. 9, Kemanggisan, Palmerah, Jakarta Barat 11480 \\ tax_ez@yahoo.com
}

\begin{abstract}
Indonesia has 'self assessment' tax system to fulfill taxpayer obligation in complying Tax Laws and Regulations. In fact tax administration could occasionally make tax audit resulting a different assessmentand therefore taxpayers still have to pay. Any tax dispute of the tax administrations assessment will be reviewed by filling complain, and later any further tax assessments dispute will be solved by bringing the case by appealing to Tax Court. Study uses field data and other related readings,in field research is collecting related data including appeal letter and the Tax courts process, as well as library research collecting related data to support the analysis. Result of the research on three tax payers shows caused by some taxs or fiscals corrections, and in the tax court is neither not supported with reliable evidences, nor tax payers do not completely fulfill tax laws and regulations. The study on the cases suggesting that taxpayers have always to provide all related documents to make tax audits done accordingly, and tax payers could explain them to judges, andsuggestions for tax court could possibly to complete the review in six moths or sooner to avoid unnecessary additional cost to taxpayers on penalty.
\end{abstract}

Keywords: tax disputes, tax inspection, tax appeal, tax court

\begin{abstract}
ABSTRAK
Sistem perpajakan di Indonesia adalah self assessment dalam pemenuhan kewajiban Wajib Pajak dengan benar sesuai Undang-undang dan Peraturan Perpajakan. Namun Fiskus masih bisa melakukan pemeriksaan yang berbeda dengan perhitungan Wajib Pajak dan mengeluarkan Surat Ketetapan. Solusi sengketa pajak atas ketetapan Fiskus, dapat melalui keberatan dan jika keputusannya masih belum diterima, Wajib Pajak, dapat mengajukan banding ke Pengadilan Pajak. Penelitian memakai data lapangan dan kepustakaan, dan penelitian lapangan mengumpulkan data terkait juga surat banding, proses sidang Pengadilan Pajak, serta penelitian pustaka dengan data dan referensi pendukung.Hasil penelitian kasus sampling beberapa (tiga) Wajib Pajak, diawali koreksi Fiskus, dan proses persidangan atas koreksi fiskal namun Wajib Pajak tidak melengkapi bukti ataubelum melaksanakan peraturan perpajakan. Atashasil penelitiankasus, penulis menyarankan tersedianya semua dokumen yang perlu agar pemeriksaan dapat berjalan sesuai bukti dan Wajib Pajak dapat memberikan pendapatnya dalam persidangan dari bukti yang ada. Saran untuk Majelis, agar diusahakan proses lebih cepat menyelesaikan sengketa bila mungkin dapat diselesaikan dalam enam bulan agar sanksi pajak terhadap Wajib Pajak tidak terlalu besar.
\end{abstract}

Kata kunci: sengketa pajak, pemeriksaan pajak, keberatan pajak, banding pajak 


\section{PENDAHULUAN}

\section{Pajak di Indonesia}

Menurut Soemitro dalam Mardiasmo (2008) menulis bahwa pajak adalah iuran rakyat kepada kas negara berdasarkan undang-undang (yang dapat dipaksakan) dengan tiada mendapat jasa timbal (kontraprestasi) yang langsung dapat ditunjukkan dan yang digunakan untuk membayar pengeluaran umum. Selain itu, Andriani (2000) mendefinisikan bahwa pajak adalah iuran kepada negara (yang dapat dipaksakan) terutama oleh yang wajib membayarnya menurut peraturan-peraturan dengan tidak mendapat prestasi kembali, yang langsung dapat ditunjuk, yang gunanya adalah untuk membiayai pengeluaran umum berhubungan dengan tugas negara menyelenggarakan pemerintahan.

Pengertian pajak menurut Pasal 1 ayat (1) Undang-undang Nomor 28 Tahun 2007 tentang Ketentuan Umum dan Tata Cara Perpajakan ditegaskan: "Pajak adalah kontribusi wajib kepada negara yang terutang oleh orang pribadi atau badan yang bersifat memaksa berdasarkan Undang-Undang, dengan tidak mendapat imbalan secara langsung dan digunakan untuk keperluan negara bagi sebesarbesarnya kemakmuran rakyat". Sedangkan, pengertian pajak dalam Pasal 1 ayat (2) Undang-undang Nomor 14 Tahun 2002 tentang Pengadilan Pajak diperluas: "Pajak adalah semua jenis pajak yang dipungut oleh Pemerintah Pusat, termasuk Bea Masuk dan Cukai, dan pajak yang dipungut oleh Pemerintah Daerah, berdasarkan peraturan perundang-undangan yang berlaku".

Dari beberapa definisi lain secara umumnya memberikan batasan arti yang sama, maka dari pendapat tersebut diatas selanjutnya dapat disimpulkan bahwa pajak memiliki unsur, yaitu: (1) iuran dari rakyat kepada negara, yang berhak memungut pajak hanyalah negara; (2) berdasarkan undangundang, pajak yang dipungut berdasarkan undang-undang serta aturan pelaksanaannya; (3) tanpa jasa timbal balik atau kontraprestasi dari negara yang secara langsung; (4) digunakan untuk membiayai rumah tangga negara, yakni pengeluaran-pengeluaran yang bermanfaat bagi masyarakat luas.

Sebenarnya pajak dalam pelaksanaannya memiliki beberapa fungsi atau tujuan, namun secara kelompok serta garis besarnya dan memperhatikan tujuan atau fungsi pajak yang mudah terlihat dan dirasakan dapat dikelompokkan dalam dua bagian,pertama Fungsi Budgeter (anggaran) yaitu fungsi untuk memasukkan uang ke kas negara dengan tujuan untuk membiayai pengeluaran-pengeluaran negara. Kedua adalah Fungsi Regulerend (mengatur) yaitu fungsi yang dipergunakan untuk mengatur atau untuk mencapai tujuan tertentu di bidang ekonomi, politik, sosial, budaya, pertahanan dan keamanan.

Sistem pemungutan Pajak dapat dterjadi atau dilakukan berbeda antara satu nega dengan negara lainnya, namun secara prinsip hanya memiliki lebih dari satu jenis atau cara pemungutan atau pengenaan, dan menurut Mardiasmo (2008) ada tiga prinsip yaitu: (1) official assessment system adalah suatu sistem yang memberi wewenang kepada pemerintah (fiskus) untuk menentukan besarnya pajak yang terutang oleh Wajib Pajak, dengan ciri: wewenang untuk menentukan besarnya pajak terutang ada pada fiskus, Wajib Pajak bersifat pasif, dan utang pajak timbul setelah dikeluarkan surat ketetapan pajak oleh fiskus; (2) self assessment system adalah suatu sistem pemungutan pajak yang memberikan wewenang kepada Wajib Pajak untuk menentukan sendiri besarnya pajak yang terutang, dengan ciri: wewenang untuk menentukan besarnya pajak terutang ada pada Wajib Pajak sendiri, Wajib Pajak aktif, mulai dari menghitung, menyetor dan melaporkan sendiri pajak yang terutang, fiskus tidak ikut campur dan hanya mengawasi; (3) withholding system adalah suatu sistem pemungutan pajakyang memberi wewenang kepada pihak ketiga (bukan fiskus dan bukan Wajib Pajak yang bersangkutan) untuk menentukan besarnya pajak yang terutang oleh Wajib Pajak. Ciricirinya wewenang menentukan besarnya pajak yang terutang ada pada pihak ketiga, pihak selain fiskus dan Wajib Pajak. 
Selanjutnya batasan dan definisi pengertian dengan Wajib Pajak dalam Undang-undang Nomor 28 Tahun 2007 perubahan ketiga atas Undang-undang Nomor 6 Tahun 1983 tentang Ketentuan Umum dan Tata Cara Perpajakan disebutkan dalam Pasal 1 ayat (2), disebutkan: "Wajib Pajak adalah orang pribadi atau badan, meliputi pembayar pajak, pemotong pajak, dan pemungut pajak, yang mempunyai hak dan kewajiban perpajakan sesuai dengan ketentuan perundang-undangan perpajakan". Pengertian badan adalah cukup luas tidak terbatas sebagai badan hukum, maka di bagian selanjutnya dalam Pasal 1 ayat (3) dilengkapi dengan uraian khusus tentang badan: "Badan adalah sekumpulan orang dan/atau modal yang merupakan kesatuan baik yang melakukan usaha maupun yang tidak melakukan usaha yang meliputi perseroan terbatas, perseroan komanditer, perseroan lainnya, badan usaha milik negara atau badan usaha milik daerah dengan nama dan dalam bentuk apapun, firma, kongsi, koperasi, dana pensiun, persekutuan, perkumpulan, yayasan, organisasi massa, organisasi sosial politik, atau organisasi lainnya, lembaga dan bentuk badan lainnya termasuk kontrak investasi kolektif dan bentuk usaha tetap".

\section{Timbul dan Hapusnya Utang Pajak}

Terdapat dua pendapat yang berbeda yang mengatur bagaimana timbulnya utang pajak dalam hukum pajak, Ilyas \& Burton (2008) menyebutkan pertama pendapat materiil menyatakan bahwa utang pajak timbul saat diundangkannya, artinya apabila suatu undang-undang pajak diundangkan oleh pemerintah, maka saat itulah timbulnya utang pajak sepanjang apa yang diatur dalam undangundang tersebut menimbulkan suatu kewajiban bagi seseorang menjadi terutang pajak. Kedua pendapat formil menyatakan bahwa utang pajak timbul saat dikeluarkannya Surat Ketetapan Pajak oleh pemerintah atau Direktorat Jenderal Pajak (fiskus), artinya bahwa seseorang baru diketahui mempunyai utang saat fiskus menerbitkan Surat Ketetapan Pajak atas namanya serta besarnya pajak yang terutang.

Sejak timbul hutang pajak kakan menimbulkan kewajiban dibayar dalam waktu 30 (tiga puluh) hari atau sebulan sejak diterbitkannya Surat Ketetapan Pajak, dan salah hapusnya utang pajak menurut Mardiasmo (2008) dapat disebabkan beberapa hal yaitu: (1) pembayaran, yaitu Wajib Pajak melakukan pembayaran atas utang pajaknya ke kas negara atau tempat lain yang ditunjuk oleh Menteri Keuangan; (2) kompensasi, adalah cara menghapus utang pajak yang dilakukan melalui cara pemindahan kelebihan pajak pada suatu jenis pajak dengan menutup kekurangan utang pajak atas jenis pajak yang sama atau jenis pajak lainnya; (3) daluwarsa utang pajak bisa terjadi karena lampaunya waktu penetapan pajak maupun karena lampaunya waktu proses penagihan pajak. Daluwarsa utang pajak dimaksudkan agar suatu kepastian hukum bagi Wajib Pajak untuk suatu masa tertentu yang ditentukan undang-undang tidak lagi mempunyai utang pajak; (4) penghapusan utang pajak dapat disebabkan hal-hal, yaitu: Wajib Pajak meninggal dunia dengan tidak meninggalkan warisan dan tidak mempunyai ahli waris atau ahli waris tidak dapat ditemukan, Wajib Pajak tidak mempunyai harta kekayaan lagi yang dibuktikan berdasarkan surat keterangan dari Pemerintah Daerah setempat, atau sebab lain, misalnya Wajib Pajak tidak dapat ditemukan lagi atau dokumen tidak dapat ditemukan lagi disebabkan keadaan yang tidak dapat dihindarkan seperti kebakaran, bencana alam, dan sebagainya.

Dengan telah hapusnya hutang pajak karena salah satu dari kemungkinan tersebut maka fiskus tidak bisa melakukan penagihan lagi kepada Wajib Pajak, dan di pihak Wajib Pajak tidak ada kewajiban untuk membayar kepada fiskus.

\section{Cara Pengenaan Utang Pajak}

Beberapa pengenaan pajak menurut teori dalam pajak, Ilyas \& Burton (2008) terdapat tiga cara pengenaan pajak yang mungkin dapat dilakukan, yaitu dilakukan di depan atau Stelsel Fiksi, dilakukan di belakang atau Stelsel riel, dan pengenaan secara Campuran. Pengenaan di depan merupakan suatu cara pengenaan pajak yang didasarkan atas suatu anggapan (fiksi) yang tergantung 
pada ketentuan bunyi undang-undang. Misalnya penghasilan seorang Wajib Pajak pada tahun berjalan dianggap sama dengan penghasilan pada tahun sebelumnya, tanpa memperhatikan kondisi sesungguhnya atas besarnya penghasilan pada tahun berjalan yang seharusnya menjadi dasar penetapan besarnya utang pajak pada tahun berjalan. Dengan anggapan demikian, maka fiskus dapat dengan mudah menetapakan besarnya utang pajak tahun yang akan datang. Pasal 25 Undang-Undang Pajak Penghasilan merupakan suatu cara pemajakan di depan yang dilakukan dengan suatu perhitungan (formula) tertentu.

Pengenaan di belakang merupakan suatu cara pengenaan pajak didasarkan pada keadaan yang sesungguhnya (riil) atau nyata, yang diperoleh dalam suatu tahun pajak. Karena besarnya penghasilan yang diperoleh seorang Wajib Pajak baru diketahui pada akhir tahun, maka pengenaan baru dilakukan setelah berakhirnya suatu tahun pajak. Dengan demikian, utang pajak baru akan dikenakan di belakang sesudah berakhirnya tahun pajak yang bersangkutan.Pengenaan cara campuran merupakan cara pengenaan pajak yang mendasar pada kedua cara pengenaan pajak fiksi dan riil. Pada awal tahun pajak, fiskus mengenakan pajak berdasarkan anggapan yang ditentukan dalam undang-undang, yang selanjutnya setelah berakhir tahun pajak dilakukan pengenaan pajak berdasarkan keadaan yang sesungguhnya (riil). Undang-undang Pajak Penghasilan pada prinsipnya mendasarkan pengenaan pajak dengan cara campuran ini.

\section{Pemeriksaan Pajak}

Walaupun sistem perpajakankita memberian kepercayaan kepada masyarakat atau Wajib Pajak, maka untuk memastikan bahwa mereka melaksanakan kewajiban pajaknya dengan benar sesuai ketentuan dan Undang-undang Pajak, maka dalam kondisi tertentu pemerintah atau fiskus dapat melakukan pemeriksaan pajak. Dasar hukum pemeriksaan pajak Pasal 29 ayat (1) Undang-undang Nomor 28 Tahun 2007 tentang Ketentuan Umumdan Tata Cara Perpajakan menegaskan "Dirjen Pajak berwenang melakukan pemeriksaan untuk menguji kepatuhan pemenuhan kewajiban perpajakan Wajib Pajak dan untuk tujuan lain dalam rangka melaksanakan ketentuan peraturan perundangundangan perpajakan".

Pengertian Pemeriksaan menurut Undang-undang Nomor 28 Tahun 2007 Pasal 1 angka 25 tentang Kentuan Umum dan Tata Cara Perpajakan disebutkan "Pemeriksaan adalah serangkaian kegiatan menghimpun dan mengolah data, keterangan, dan/atau bukti yang dilaksanakan secara objektif dan profesional berdasarkan suatu standar pemeriksaan untuk menguji kepatuhan pemenuhan kewajiban perpajakan dan/atau untuk tujuan lain dalam rangka melaksanakan ketentuan peraturan perundang-undangan perpajakan". Menurut Mardiasmo (2008) yang menjadi sasaran pemeriksaan dan penyelidikan adalah untuk mencari: interprestasi undang-undang yang tidak benar; kesalahan hitung; penggelapan secara khusus dari penghasilan; pemotongan dan pengurangan tidak sesungguhnya, yang dilakukan wajib pajak dalam melaksanakan kewajiban perpajakannya.

Proses penelitian atau pemeriksaan oleh fiskus dapat saja dihentikan apabila dianggap perlu, namun pada umumnya akan berakhir dengan kesimpulan hasil pemeriksaan dengan menerbitkan produk hukum oleh fiskus.Surat ketetapan pajak adalah hasil produk hukum dari proses penelitian atau pemeriksaaan pajak yang diatur dalam Undang-undang tentang Ketentuan Umum dan Tata Cara Perpajakan Nomor 28 Tahun 2007 Pasal 1, yaitu "Surat Ketetapan Pajak adalah surat ketetapan yang meliputi Surat Ketetapan Pajak Kurang Bayar, Surat Ketetapan Pajak Kurang Bayar Tambahan, Surat Ketetapan Pajak Nihil, atau Surat Ketetapan Pajak Lebih Bayar", maka kemungkinan jenis Surat Ketetapan Pajak adalah: (1) Surat Ketetapan Pajak Kurang Bayar (SKPKB), adalah surat ketetapan pajak yang menentukan besarnya jumlah pokok pajak, kredit pajak, kekurangan pembayaran pokok pajak, besarnya sanksi administrasi, dan jumlah pajak yang masih harus dibayar; (2) Surat Ketetapan Pajak Kurang Bayar Tambahan (SKPKBT), adalah Surat Ketetapan Pajak yang menentukan tambahan atas jumlah pajak yang telah ditetapkan; (3) Surat Ketetapan Pajak Lebih Bayar (SKPLB),merupakan surat ketetapan pajak yang menentukan jumlah kelebihan pembayaran pajak 
karena jumlah kredit pajak lebih besar dari pajak yang terutang atau seharusnya tidak terutang; (4) Surat Ketetapan Pajak Nihil (SKPN), adalah surat ketetapan pajak yang menentukan jumlah pokok pajak sama besarnya dengan jumlah kredit pajak atau pajak tidak terutang dan tidak ada kredit pajak; (5) Surat Tagihan Pajak (STP), adalah surat untuk melakukan tagihan pajak dan/atau sanksi administrasi berupa bunga dan/atau denda.

Karena surat ketetapan pajak adalah hasil hitungan oleh fiskus maka tidak mustahil bisa berbeda dengan apa yang telah dihitung oleh Wajib Pajak, karena adanya perbedaan pemahaman ketentuan atau Undang-undang Pajak atau perbedaan data yang dipakai dalam perhitungan oleh fiskus. Perbedaan hitungan antara fiskus dan Wajib Pajak tersebut merupakan keadaan yang menimbulkan adanya salah satu sengketa pajak.

\section{Sengketa Pajak}

Sengketa pajak terjadi karena ketidaksamaan presepsi atau perbedaan pendapat antara Wajib Pajak dengan petugas pajak mengenai penetapan pajak terutang yang diterbitkan atau adanya tindakan penagihan yang dilakukan oleh Direktorat Jenderal Pajak. Pengertian Sengketa Pajak umumnya diawali diterbitkannya surat ketetapan pajak atau surat tindakan penagihan pajak. Surat ketetapan pajak dimaksud adalah Surat Ketetapan Pajak Kurang Bayar (SKPKB), Surat Ketetapan Pajak Kurang Bayar Tambahan (SKPKBT), Surat Ketetapan Pajak Lebih Bayar (SKPLB), Surat Ketetapan Pajak Nihil (SKPN). Selain itu sengketa juga bisa timbul karena adanya pemotongan atau pemungutan yang dilakukan oleh pihak ketiga pelaku pemotongan atau pemungutan pajak. Untuk menyelesaikan Sengketa Pajak yang dapat dilakukan Wajib Pajak adalah meliputi proses keberatan, banding, peninjauan kembali, dan gugatan. Upaya hukum keberatan atas ketetapan pajak diajukan ke Direktorat Jenderal Pajak, sedang upaya hukum Banding dan Gugatan diajukan ke Pengadilan Pajak (PP). Khusus upaya hukum Peninjauan Kembali (PK) diajukan ke Mahkamah Agung (MA). Namun demikian, ada upaya hukum dengan nama peninjauan kembali (huruf kecil) yang diajukan ke Direktorat Jenderal Pajak" (Ilyas \& Burton).

Definisi Sengketa Pajak menurut Undang-undang Nomor 14 Tahun 2002 tentang Pengadilan Pajak, "Sengketa yang timbul dalam bidang perpajakan antara Wajib Pajak atau Penanggung Pajak dengan pejabat yang berwenang sebagai akibat dikeluarkannya keputusan yang dapat diajukan Banding atau Gugatan kepada Pengadilan Pajak berdasarkan peraturan perundang-undangan perpajakan, termasuk Gugatan atas pelaksanaan penagihan berdasarkan Undang-undang Penagihan Pajak dengan Surat Paksa". Lebih lanjut dipertegas bahwa "Dengan demikian sengketa yang timbul sebelum keluar keputusan Direktorat Jenderal Pajak dimaksud, seperti sengketa yang terjadi di dalam pemeriksaan misalnya, tidak dapat dianggap sebagai Sengketa Pajak. Rumusan Sengketa Pajak tidak mengharuskan adanya penyelesaian di Pengadilan Pajak, tetapi hanya memberi batasan bahwa keputusan tersebut dapat diajukan Banding atau Gugatan ke Pengadilan Pajak. Atas dasar itu, Sengketa Pajak bisa diselesaikan di Direktorat Jenderal Pajak atau di Pengadilan Pajak" (IAI, 2009).

Menurut Oktavia \& Setyawan (2007), "Terdapat dua sisi persepsi obyek yaitu antara sudut pandang Fiskus dan Wajib Pajak sebagai akibat dari adanya perbedaan penafsiran dan pendirian mengenai ketentuan hukum pajak yang memicu terjadinya Sengketa Pajak, ternyata dapat diselesaikan melalui upaya hukum yakni peradilan administrasi dalam pengajuan keberatan dan banding".

\section{Keberatan Pajak}

Berdasarkan Pasal 25 ayat (1) Undang-undang Ketentuan Umum dan Tata Cara Perpajakan Nomor 28 Tahun 2007, "Wajib Pajak dapat mengajukan keberatan, dengan menyampaikan surat keberatan, hanya kepada Direktorat Jenderal Pajak atas suatu: Surat Ketetapan Pajak Kurang Bayar; 
Surat Ketetapan Pajak Kurang Bayar Tambahan; Surat Ketetapan Pajak Lebih Bayar; Surat Ketetapan Pajak Nihil; Pemotongan atau pemungutan oleh pihak ketiga berdasarkan ketentuan peraturan perundang-undangan perpajakan". Dengan demikian dasar hukum keberatan yaitu mengacu kepada: Pasal 25, 26, dan 26 huruf a Undang-undang Nomor 6 Tahun 1983 Sebagaimana Telah Diubah Terakhir Dengan Undang-undang Nomor 28 Tahun 2007 tentang KetentuanUmum dan Tata Cara Perpajakan; Peraturan Menteri Keuangan Nomor 194/PMK.03/2007 tentang Tata Cara Pengajuan dan Penyelesaian Keberatan.

\section{Proses Penyampaian Surat Keberatan}

Menurut Pardiat (2009), surat keberatan disampaikan oleh Wajib Pajak ke Kantor Pelayanan Pajak tempat Wajib Pajak terdaftar dan/atau tempat Pengusaha Kena Pajak dikukuhkan melalui tiga pilihan, yaitu pertama Penyampaian secara langsung, kedua melalui Pos dengan bukti pengiriman surat; atau dengan Cara lain.Termasuk dalam pengertian penyampaian surat keberatan secara langsung adalah penyampaian surat keberatan melalui Kantor Penyuluhun dan Pengamatan Potensi Perpajakan (KP4) atau Kantor Pelayanan Penyuluhan dan Konsultasi Perpajakan (KP2KP) dalam wilayah kerja Kantor Pelayanan Pajak tempat Wajib Pajak terdaftar dan/atau tempat Pengusaha Kena Pajak dikukuhkan.

Penyampaian surat keberatan melalui cara lain meliputi dua pilihan, yaknimelalui perusahaan jasa ekspedisi atau jasa kurir dengan bukti pengiriman surat, dan secara e-Filling melalui Penyedia Jasa Aplikasi atau Aplication Service Provider (ASP). Atas penyampaian surat keberatan secara langsung diberikan tanda penerimaan surat dan penyampaian surat keberatan dengan e-filling melalui Penyedia Jasa Aplikasi atau Aplication Service Provider (ASP) diberikan bukti penerimaan Elektronik. Bukti pengiriman surat lewat pos, melalui perusahaan jasa ekspedisi atau jasa kurir atau tanda penerimaan surat secara langsung serta Bukti Penerimaan Elektronik menjadi bukti penerimaan surat keberatan. Dalam Peraturan Menteri Keuangan Nomor 194/PMK.03/2007 mulai berlaku 1 Januari 2008, mengatur: (1) perusahaan jasa ekspedisi atau jasa kurir adalah perusahaan yang berbentuk hukum yang memberikan jasa pengiriman surat jenis tertentu termasuk surat pengiriman surat keberatan ke Direktorat Jenderal Pajak; (2) penyampaian surat keberatan secara elektronik yang selanjutnya disebut $e$-Filling adalah suatu cara penyampaian surat keberatan yang dilakukan secara online yang real time melalui Penyedia Jasa Aplikasi atau Aplication Service Provider (ASP).

\section{Syarat Permohonan Pengajuan Keberatan}

Sesuai Undang-undang Ketentuan Umum dan Tata Cara Perpajakan Nomor 28 Tahun 2007 Pasal 25, pengajuan keberatan dalam Surat Keberatan harus memenuhi syarat: (1) diajukan secara tertulis dalam bahasa Indonesia; (2) menyebutkan jumlah pajak yang terutang, yang dipotong atau dipungut, atau jumlah rugi menurut perhitungan Wajib Pajak dengan disertai alasan yang menjadi dasar perhitungan; (3) satu surat keberatan diajukan hanya untuk satusurat ketetapan pajak, untuk satu pemotongan pajak, atau untuk satu pemungutan pajak; (4) Wajib Pajak telah melunasi pajak yang masih harus dibayar paling sedikit sejumlah yang telah disetujui Wajib Pajak dalam pembahasan akhir hasil pemeriksaan; (5) diajukan dalam jangka waktu tiga bulan sejak tanggal dikirim Surat Ketetapan Pajak atau sejak tanggal pemotongan atau pemungutan pajak oleh pihak ketiga, kecuali Wajib Pajak dapat menunjukkan bahwa jangka waktu tersebut tidak dapat dipenuhi karena keadaan di luar kekuasaan Wajib Pajak (force majeur); (6) Surat keberatan ditanda tangani Wajib Pajak, dan bila surat keberatan ditanda tangani oleh bukan Wajib Pajak, surat keberatan tersebut harus dilampiri dengan surat kuasa khusus.

Dalam Surat Edaran Direktur Jenderal Pajak Nomor SE- 24/PJ.43/2000, force majeur adalah suatu keadaan yang terjadi di luar kekuasaan manusia seperti banjir, kebakaran, petir, gempa bumi, wabah, perang, perang saudara, huru-hara, pemogokan, pembatasan oleh penguasa dari suatu pemerintahan, pembatasan perdagangan oleh suatu undang-undang atau peraturan pemerintah, atau 
dikarenakan suatu keadaan atau kejadian alamiah yang tidak dapat diduga sebelumnya. Untuk membuktikan Wajib Pajak mengalami force majeur harus mendapatkan rekomendasi (pengesahan) dari aparat yang berwenang setempat minimal Camat atau Kepolisian setempat.

\section{Keputusan Keberatan}

Direktorat Jenderal Pajak dalam waktu paling lama 12 (dua belas) bulan sejak tanggal surat keberatan diterima harus memberi keputusan atas keberatan yang diajukan. Apabila jangka waktu tersebut telah terlampaui dan fiskus tidak menerbitkan surat keputusan keberatan, keberatan yang diajukan Wajib Pajak dianggap dikabulkan dan Direktur Jenderal Pajak wajib menerbitkan Surat Keputusan Keberatan sesuai dengan keberatan Wajib Pajak.Keputusan Direktur Jeenderal Pajak atas keberatan dapat berupa mengabulkan seluruhnya, atau sebagian, menolak, atau menambah besarnya jumlah pajak yang masih harus dibayar.

Apabila Wajib Pajak masih belum menerima atau setuju dengan isi keputusan keberatan dan masih tetap merasa keberatan juga, Wajib Pajak masih dapat menempuh upaya hukum berikutnya yaitu dengan mengajukan banding kepada Pengadilan Pajak sesuai dengan Pasal 27 Undang-undang Ketentuan Umum dan Tata Cara Perpajakan Nomor 28 Tahun 2007.

\section{PEMBAHASAN}

\section{Banding Pajak}

Sesuai Pasal 27 ayat (1) Undang-undang Nomor 28 Tahun 2007 tentang Ketentuan Umum dan Tata Cara Perpajakan, "Wajib Pajak dapat mengajukan permohonan banding hanya kepada badan peradilan pajak atas Surat Keputusan Keberatan". Dengan demikian, proses pengajuan banding hanya dapat dilakukan apabila telah melalui proses keberatan.Dalam ketentuan Pasal 1 Undang-undang Nomor 14 Tahun 2002 tentang Pengadilan Pajak disebutkan "Banding adalah upaya hukum yang dapat dilakukan oleh Wajib Pajak atau Penanggung Pajak terhadap suatu keputusan yang dapat diajukan banding berdasarkan peraturan perundang-undangan perpajakan yang berlaku".

\section{Proses Penyampaian Surat Banding}

Mekanisme pengajuan banding menurut Mardiasmo (2008), Wajib Pajak dapat mengajukan Banding, dengan Tata Cara Penyelesaian Banding: (1) Wajib Pajak mengajukan permohonan banding hanya kepada badan peradilan pajak atas suatu Surat Keputusan Keberatan; (2) Putusan Pengadilan Pajak adalah putusan pengadilan khusus di lingkungan peradilan tata usaha negara; (3) Permohonan banding diajukan dalam tiga bulan sejak Surat Keputusan Keberatan diterima, dengan cara: tertulis dalam bahasa Indonesia, mengemukakan alasan-alasan yang jelas, melampirkan salinan Surat Keputusan Keberatan; (4) Jumlah pajak yang belum dibayar saat pengajuan permohonan banding belum merupakan pajak yang terutang sampai dengan Putusan Banding diterbitkan; (5) Bila permohonan banding ditolak atau dikabulkan sebagian, Wajib Pajak dikenakan sanksi administrasi atau denda 100\% (seratus persen) dari jumlah pajak sesuai Putusan Banding dikurangi pembayaran pajak yang telah dibayar sebelum mengajukan keberatan (Undang-undang Ketentuan Umum dan Tata Cara Perpajakan nomor 28 Tahun 2007 pasal 27 ayat (5) huruf d; (6) Bila pengajuan keberatan atau banding dikabulkan sebagian atau seluruhnya, yang menyebabkan kelebihan pembayaran pajak, kelebihan pembayarannya dikembalikan ditambah imbalan bunga 2\% (dua persen) per bulan maksimal 24 (dua puluh empat) bulan dengan ketentuan untuk: Surat Ketetapan Pajak Kurang Bayar dan Surat Ketetapan Pajak Kurang Bayar Tambahan dihitung sejak tanggal pembayaran yang menyebabkan kelebihan pembayaran pajak sampai dengan diterbitkannya Surat Keputusan Keberatan, 
Putusan Banding, atau untuk Surat Ketetapan Pajak Nihil dan Surat Ketetapan Pajak Lebih Bayar dihitung sejak tanggal penerbitan surat ketetapan pajak sampai dengan diterbitkannya Surat Keputusan Keberatan, Putusan Banding.

\section{Syarat Permohonan Pengajuan Banding}

Wajib Pajak dapat mengajukan upaya hukum Banding apabila memenuhi persyaratan berdasarkan Undang-undang Nomor 14 Tahun 2002 tentang Pengadilan Pajak Pasal 35 dan Pasal 36: (1) banding diajukan dengan Surat Banding dalam bahasa Indonesia kepada Pengadilan Pajak; (2) banding diajukan dalam jangka waktu tiga bulan sejak tanggal diterima Keputusan Direktorat Jenderal Pajak megenai keberatan perpajakan yang diajukan banding, atau 60 (enam puluh) hari sejak tanggal diterimanya Keputusan Direktorat Jenderal Bea dan Cukai mengenai keberatan kepabeanan dan cukai; (3) jangka waktu tiga bulan tidak mengikat apabila jangka waktu dimaksud tidak dapat dipenuhi karena keadaan di luar kekuasaanPemohon Banding; (4) terhadap satu Keputusan diajukan satu Surat Banding; (5) banding diajukan dengan disertai alasan-alasan yang jelas, dan dicantumkan tanggal diterima surat keputusan yang dibanding; (6) pada Surat Banding dilampirkan salinan Keputusan yang dibanding; (7) banding hanya dapat diajukan apabila jumlah yang terutang dimaksud telah dibayar 50\% (lima puluh persen) dari jumlah pajak terutang.

Sesuai Undang-undang Nomor 14 Tahun 2002 tentang Pengadilan Pajak Pasal 37 dan 38, Pemohon Banding yang dapat mengajukan permohonan Banding adalah: (1) banding dapat diajukan oleh Wajib Pajak, ahli warisnya, seorang pengurus, atau kuasa hukumnya; (2) apabila dalam proses Banding, Pemohon Banding meninggal dunia, Banding dapat dilanjutkan oleh ahli warisnya, kuasa hukum dari ahli warisnya atau pengampunya dalam hal Pemohon Banding pailit; (3) apabila selama proses Banding Pemohon Banding melakukan penggabungan, peleburan, pemecahan/pemekaran usaha, atau likuidasi, permohonan dimaksud dapat dilanjutkan oleh pihak yang menerima pertanggungjawaban karena penggabungan, peleburan, pemecahan/pemekaran usaha, atau likuidasi dimaksud; (4) pemohon Banding dapat melengkapi Surat Bandingnya untuk memenuhi ketentuan yang berlaku sepanjang masih dalam jangka waktu.

\section{Proses Banding Acara Biasa}

Banding pajak di Peradilan Pajak dapk diproses dalam dua kemungkinan, pertama adalah termasuk banding acara biasa atau kedua banding dengan acara cepat, dan yang dilakukan Wajib Pajak apabila Banding Acara Biasa, prosesnya adalah: (1) Pemohon Banding Mengirimkan Surat Permohonan Banding (SPB) selambatnya tiga bulan sejak menerima Surat Keputusan Keberatan atau sesuai undang-undang yang bersangkutan kepada Sekretariat Pengadilan Pajak (Set.PP); (2) Sekretariat Pengadilan Pajak mengirimkan Surat Permohonan Banding selambatnya 14 (empat belas) hari sejak menerima Surat Permohonan Banding dari Pemohon Banding kepada Pejabat Terbanding; (3) Pejabat Terbanding mengirimkan Surat Uraian Banding (SUB) selambat-selambatnya tiga bulan sejak menerima Surat Permohonan Banding; (4) Sekretariat Pengadilan Pajak mengirimkan salinan Surat Uraian Banding selambatnya 14 (empat belas) hari sejak menerima Surat Permohonan Banding dari Pejabat Terbanding kepada Pemohon Banding; (5) Pemohon Banding mengirimkan Surat Bantahan (SBt) selambatnya 30 (tiga puluh) hari sejak menerima salinan Surat Uraian Banding kepada Sekretariat Pengadilan Pajak; (6) Sekretariat Pengadilan Pajak mengirimkan Salinan Surat Uraian Banding selambatnya 14 (empat belas) hari sejak menerima Surat Permohonan Banding (SPB) dari Pemohon Banding kepada Pejabat Terbanding; (7) Ketua Pengadilan menunjuk Majelis Hakim untuk menyidangkan perkara sengketa terkait; (8) Majelis Hakim mulai bersidang sejak diterimanya Surat Permohonan Banding; (9) Majelis Hakim memutuskan perkara dalam jangka waktu 12 (dua belas) bulan sejak Surat Permohonan Banding diterima; (10) Sekretariat Pengadilan Pajak mengirimkan salinan Putusan selambatnya 30 (tiga puluh) hari sejak Putusan diucap; (11) Pemohon Banding dan Pejabat Terbanding melaksanakan putusan selambatnya 30 (tiga puluh) hari sejak menerima salinan Putusan. 
Banding yang kelompok kedua atau banding acara cepat, dan yang dilakukan Wajib Pajak apabila Banding Acara Cepat, prosesnya sebagai berikut: (1) Pemohon banding mengirimkan Surat Permohonan Banding (SPB) selambatnya 3 bulan sejak menerima Surat Keputusan Keberatan atau sesuai undang-undang yang bersangkutan kepada Sekretariat Pengadilan Pajak; (2) Ketua Pengadilan menunjuk Majelis Hakim atau Anggota Tunggal untuk menyidangkan perkara sengketa terkait; (3) jika syarat formal terpenuhi, maka Majelis Hakim atau Anggota Tunggal melakukan Penetapan dan meneruskan ke Proses Banding Acara Biasa; (4) jika syarat formal tidak terpenuhi, maka Majelis Hakim atau Majelis Tunggal membuat Putusan selambatnya 30 hari; (5) Sekretariat Pengadilan Pajak mengirimkan salinan Putusan selambatnya 30 hari sejak Putusan diucap; (6) Pemohon Banding dan Pejabat Terbanding melaksanakan putusan selambatnya 30 hari sejak menerima salinan putusan.

\section{Putusan Banding}

Secara umum kecuali acara cepat atas dan atas gugatan, Pengadilan Pajak dalam waktu paling lama 12 (dua belas) bulan sejak tanggal surat banding diterima harus memberi putusan atas banding yang diajukan. Apabila jangka waktu tersebut telah terlampaui dan Pengadilan Pajak tidak menerbitkan surat putusan banding, maka banding yang diajukan Wajib Pajak dianggap dikabulkan dan Pengadilan Pajak menerbitkan Surat Putusan Banding sesuai dengan permohonan banding Wajib Pajak. Putusan Banding oleh Pengadilan Pajak atas permohonan banding dapat berupa mengabulkan seluruhnya, atau sebagian, menolak, atau menambah besarnya jumlah pajak yang masih harus dibayar.

Proses keberatan pajak sering disebut sebagai peradilan doleansi atau peradilam administrasi karena masih dilakukan di dalam organisasi fiskus, yang bertindak sebagai pihak yang di protes merangkap pihak yang mempertimbangkan protes dalam bentuk keberatan pajak, sehingga berbeda dengan banding pajak. Apabila Wajib Pajak masih belum menerima atau setuju dengan isi keputusan banding dan masih tetap merasa tidak sependapat juga, Wajib Pajak masih dapat menempuh upaya hukum berikutnya yaitu dengan mengajukan proses ke Makamah Agung dan atau Direktorat Jenderal Pajak sebagaimana diuraikan diatas. Diharapkan proses pencarian keadilan untuk solusi atas sengketa pajak yang bertingkat tersebut bisa mendapatkan keadilan dalam pajak.

\section{Penagihan Pajak atas Banding}

Menurut Ilyas \& Burton (2008) yang dimaksudkan dengan penagihan pajak atas banding yaitu"Sejak berlakunya Undang-undang Nomor 27 Tahun 2008 tentang perubahan atas Undangundang Ketentuan Umum dan Tata Cara Perpajakan, aspek hukum atas upaya hukum banding juga mengalami perubahan khususnya soal utang pajak seperti halnya pada keberatan. Dalam ketentuan Pasal 27 ayat (5) huruf c ditegaskan bahwa apabila Wajib Pajak mengajukan Banding, jumlah pajak yang belum dibayar pada saat mengajukan permohonan Banding belum merupakan utang pajak sampai dengan adanya Putusan Banding. Selanjutnya sebagai konsekwensi hukumnya adalah apabila permohonan banding ditolak atau dikabulkan sebagian, maka Wajib Pajak akan dikenakan sanksi adiministrasi berupa denda sebesar 100\% dari jumlah pajak berdasarkan Putusan Banding dikurangi dengan pembayaran pajak yang telah dibayar sebelummengajukan keberatan (ayat 5 huruf d)".

\section{Pencabutan Banding}

Dalam Undang-undang Pengadilan Pajak Nomor 14 Tahun 2002 Pasal 39 ditekankan perihal kemungkinan pembatalan atau pencabutan banding pajak: (1) terhadap banding dapat diajukan surat pernyataan pencabutan kepada Pengadilan Pajak; (2) banding yang dicabut sebagaimana dalam ayat (1) dihapus dari daftar sengketa dengan: penetapan Ketua dalam hal surat pernyataan pencabutan diajukan sebelum sidang dilaksanakan, penetapan Majelis/Hakim Tunggal melalui pemeriksaan dalam hal surat pernyataan pencabutan diajukan dalam sidang atas persetujuan Terbanding; (3) Banding yang telah dicabut melalui penetapan atau putusan dimaksud dalam ayat (2), tidak dapat diajukan kembali. 


\section{PENUTUP}

\section{Simpulan}

Hasil analisis sampling atas tiga kasus pajak dari tiga Wajib Pajak yang berbeda di Jakarta, dapat disimpulan bahwa Wajib Pajak masih terkadang masih belum sepenuhnya melaksanakan kewajiban perpajakannya sesuai dengan peraturan perundang-undangan yang berlaku karena masih ada akun-akun yang dikoreksi oleh Fiskus saat pemeriksaan. Dalam pemeriksaan Wajib Pajak masih belum dapat sepenuhnya memberikan data terkait pemeriksaan olehFiskus, ini terlihat dari PT 'IGP' yang tidak memberi penjelasan atau bukti authentic perihal salah satu cabang tidak ada kegiatan usaha lagi, maka Fiskus mengenakan tambahan margin 10\% sesuai Keputusan Direktur Jenderal Pajak Nomor:KEP-02/PJ.7/1991 yang telah diubah dengan Keputusan Direktur Jenderal Pajak Nomor: Kep536/PJ./2000 tentang Norma Perhitungan Penghasilan Neto Bagi Wajib Pajak Yang Wajib Menyelenggarakan Pembukuan Tetapi Tidak Menyelenggarakan Sebagaimana Mestinya. Saat pelaksanaan pemeriksaan Wajib Pajak tidak memberikan bukti-bukti yang menguatkan argumentasi, dilihat dari PT 'AP' dan PT 'VN' ada beberapa akun terutama akun pengurang penghasilan bruto yang tidak memiliki bukti yang dapat menyakinkan Majelis. Koreksi Fiskus yang dipertahankan Majelis di Pengadilan Pajak dalam persidangan:

\section{PT ‘AP’ Tahun Pajak 2004}

Koreksi atas Peredaran Usaha Rp61.700.000 sebagai penerimaan uang muka di 2004 namun dilaporkan Wajib Pajak pada 2005, seharusnya ini dilaporkan di 2004 karena Wajib Pajak menganut sistem stelsel kas. Koreksi atas Pengurang Penghasilan Bruto karena sebagian besar biaya-biaya pengurang penghasilan bruto, Wajib Pajak tidak memberikan bukti saat persidangan. Koreksi Penghasilan Lain-lain merupakan pendapatan jasa giro yang pajaknya bersifat final, sehingga tidak perlu diperhitungkan lagi dalam penghasilan kena pajak. Koreksi Kredit Pajak Rp70.078.395 karena Wajib Pajak tidak memberikan atau menunjukkan bukti potong saat persidangan.

\section{PT ‘IGP’ Tahun Pajak 2006}

Koreksi atas Peredaran Usaha karena terdapat Pajak Masukan Masa Tidak Sama dan atas koreksi peredaran usaha Rp31.612.495 Wajib Pajak menerima koreksi tersebut karena tidak memiliki bukti dan alasan yang kuat dalam persidangan. Koreksi atas Harga Pokok Penjualan karena terdapat Faktur Pajak Masukan Masa Tidak Sama.

\section{PT 'VN’ Tahun Pajak 2004}

Koreksi Penghasilan Lain-lain atas koreksi laba (rugi) selisih kurs, Wajib Pajak membebankan kerugian lain-lain ke dalam rugi selisih kurs dan Wajib Pajak tidak memberikan bukti saat persidangan. Untuk koreksi penghasilan lain-lain atas pinjaman pemegang saham karena tidak memenuhi syarat dalam Surat Direktur Jenderal Pajak Nomor:S-165/PJ.312/1992. Koreksi atas Pengurang Penghasilan Bruto, Wajib Pajak tidak memberikan bukti saat persidangan.

Analisa putusan Pengadilan Pajak yang dilakukan yaitu:

\section{PT ‘AP’ Tahun Pajak 2004}

Koreksi Atas Peredaran Usaha Rp479.933.003, penulis setuju mempertahankan koreksi Pemeriksa Rp61.700.000 karena Wajib Pajak mengunakan sistem stelsel kas sesuai Pasal 28 ayat (5) Undang-undang Nomor 28 Tahun 2007 tentang Ketentuan Umun dan Tata Cara Perpajakan. Untuk 
koreksi Rp419.600.000 sebaiknya majelis melakukan pengujian arus uang agar lebih akurat apakah Rp419.600.000 benar-benar transaksi pribadi komisaris atau hanya alasan Wajib Pajak untuk menutupi peredaran usaha yang sebenarnya. Koreksi Pengurang penghasilan bruto: menurut penulis sebagian biaya-biaya pengurang penghasilan bruto saat persidangan Wajib Pajak tidak memberikan bukti maka dari itu penulis setuju akan ketetapan Majelis dan sebagian biaya-biaya tersebut, Wajib Pajak menunjukkan bukti saat persidangan dan dapat meyakinkan Majelis untuk itu koreksi biaya yang memiliki bukti tidak dapat dipertahankan.

Koreksi penghasilan lain-lain, menurut penulis ketetapan tersebut sudah tepat karena dalam Pasal 2 Undang-undang Nomor 38 Tahun 2008 Perubahan Keempat Atas Undang-undang Nomor 7 Tahun 1983 Tentang Pajak Penghasilan di mana pendapatan jasa giro merupakan pajak yang bersifat final dan dalam Peraturan Pemerintah Nomor 131 Tahun 2000 tentang Pajak Penghasilan Atas Bunga Deposito dan Tabungan Serta Diskonto Sertifikat Bank Indonesia, yang wajib memotong pajak yang bersifat final ini adalah Bank Indonesia jadi pendapatan jasa giro sudah dikenakan pajak final oleh Bank Indonesia untuk itu tidak terutang lagi dalam pajak penghasilan badan. Berdasarkan hasil analisa penulis dapat disimpulkan bahwa penulis setuju dengan ketetapan Majelis yang tetap mempertahankan koreksi Rp1.756.705.

Koreksi Kredit Pajak Rp196.226.160, menurut penulis sebaiknya Majelis melakukan konfirmasi ke Kantor Pelayanan Pajak dimana Pajak Penghasilan Pasal 23/Surat Setoran Pajak itu dipotong untuk mendapat klarifikasi dari Kantor Pelayanan Pajak setempat dan berdasarkan bukti yang disampaikan di persidangan Wajib Pajak telah memberikan bukti potong asli dan fotokopi Rp126.147.765 karena Wajib Pajak memberikan bukti saat persidangan maka dari koreksi kredit pajak Rp126.147.765 tidak dapat dipertahankan.

\section{PT ‘IGP’ Tahun Pajak 2006}

Koreksi atas Peredaran Usaha Rp 5.273.918.675: Menurut penulis sebaiknya Majelis melakukan konfirmasi langsung ke Kantor Pelayanan Pajak Madiun untuk mendapatkan bukti yang lebih akurat tentang cabang Madiun yang tidak melakukan aktifitas/kegiatan usaha lagi dalam surat penegasan yang diberikan Kantor Pelayanan Pajak Pratama Madiun ke pihak Peneliti Keberatan Kantor Wilayah Direktorat Jenderal Pajak Jakarta Selatan. Terdapat pula Pajak Masukan Masa Tidak Sama menjadi pengurang selisih pembelian.

Koreksi Harga Pokok Penjualan Rp 1.145.551.456, menurut pendapat penulis pajak masukan dapat dikreditkan paling lama tiga bulan setelah berakhirnya masa pajak yang bersangkutan sesuai dengan Pasal 9 ayat 9 Undang-undang Nomor 18 Tahun 2000 tentang Pajak Pertambahan Nilai Barang dan Jasa dan Pajak Penjualan Atas Barang Mewah dan Wajib Pajak juga memberikan bukti berupa Surat Pembertitahuan Masa Pajak Pertambahan Nilai, Invoice, dan Faktur Pajak yang menyatakan terdapat jumlah pajak masukan masa tidak sama dan harus diperhitungkan.

\section{PT 'VN' Tahun Pajak 2004}

Koreksi Peredaran Usaha Rp54.403.170, menurut pendapat penulis seharusnya Wajib Pajak tidak men-tip ex buku besar walaupun menurut Wajib Pajak ada kesalahan jika kesalahan itu memang ada sebaiknya Wajib Pajak memberitahukan kesalahan itu kepada Pemeriksa dan jika ingin membetulkan kesalahan itu dengan cara dicoret lalu ditanda tangani kesalahan tersebut. Koreksi Harga Pokok Penjualan Rp7.588.961, menurut pendapat penulis selisih terjadi karena Pemeriksa menghitung persediaan akhir berdasarkan harga satuan dan bukti yang disampaikan Wajib Pajak yaitu kartu stok dan rekap mutasi stock barang meyakinkan Majelis untuk tidak mempertahankan koreksi Pemeriksa. Untuk lebih meyakinkan Pemeriksa seharusnya Wajib Pajak juga dapat membuktikan pembelian persediaan sebagai sample itu dapat dibuktikan dalam Uji Material Kebenaran Data/Bukti di persidangan. 
Koreksi penghasilan lain-lain Rp 2.799.480, menurut penulis Wajib Pajak tidak memberikan bukti dan alasan yang tepat serta tidak memenuhi syarat yang telah ditentukan maka dari itu koreksi Rp 2.799.480 tetap dipertahankan. Koreksi Pengurang Penghasilan Bruto Rp25.400.619, menurut penulis sebagian besar biaya pengurang penghasilan bruto dipertahankan karena Wajib Pajak tidak memberikan bukti-bukti saat persidangan dan biaya yang tidak dapat dipertahankan karena menurut Majelis biaya air dan listrik serta biaya telepon dan telex merupakan biaya yang wajar bagi suatu perusahaan. Jadi koreksi yang tetap dipertahankan Rp 15.181.333 dan koreksi yang tidak dapat dipertahankan Rp 10.219.286. Hasil putusan banding yang diajukan ketiga Wajib Pajak atas Surat Ketetapan Pajak Kurang Bayar adalah mengabulkan sebagian permohonan banding.

\section{Saran}

Saran untuk Wajib Pajak adalah (1) bagi Wajib Pajak yang mengajukan banding seharusnya menyiapkan dokumen atau data lengkap yang akan menjadi bukti dalam persidangan agar koreksi Pemeriksa tidak dapat dipertahankan dan banding yang diajukan tidak sia-sia; (2) dalam pemeriksaan seharusnya Wajib Pajak memberikan semua dokumen atau data lengkap yang diperlukan Pemeriksa agar tidak terjadi koreksi negatif maupun positif yang dilakukan Pemeriksa dan koreksi fiskal Pemeriksa sama dengan Surat Pemberitahuan Wajib Pajak; (3) bagi Wajib Pajak hendaknya menerapkan Peraturan Perpajakan yang berlaku sehingga mengetahui dengan pasti biaya yang dapat menjadi pengurang penghasilan bruto; (4) untuk Biaya-biaya yang akan menjadi pengurang penghasilan bruto seperti biaya promosi, Wajib Pajak sebaiknya membuat daftar nominatif apabila Wajib Pajak tidak dapat menunjukkan bukti seperti daftar nominatif maka biaya tersebut akan dikoreksi Fiskus dan dalam persidangan koreksi biaya tersebut akan tetap dipertahankan majelis karena tidak didukung bukti yang dapat meyakini pihak Majelis; (5) penulis menyarankan Wajib Pajak agar mengikuti perkembangan ilmu perpajakan bukan hanya Undang-undang perpajakan saja melainkan peraturan pajak lainnya dengan cara mengikuti seminar-seminar maupun training atau pelatihan yang ada.

Saran untuk Pemeriksa/Fiskus yaitu seharusnya melakukan koreksi berdasarkan bukti yang ada dan dapat dibuktikan dalam persidangan dan koreksi yang dilakukan Fiskus sesuai dengan Undang-undang perpajakan yang berlaku. Fiskus diharapkan melakukan perbandingan dengan Wajib Pajak lain yang memiliki kegiatan usaha yang sama dan berlokasi disekitar Wajib Pajak melakukan kegiatan usaha agar dapat gambaran akan usaha Wajib Pajak. Saran untuk Peneliti Keberatan yaitu seharusnya melakukan koreksi berdasarkan ketentuan perpajakan yang berlaku dan lebih objektif dalam menangani keberatan Wajib Pajak.

Saran untuk Pengadilan Pajak yaitu: (1) majelis dapat mengkonfirmasikan bukti yang didapat kepada pihak terkait agar dapat meyakini kebenaran dari bukti tersebut. Sehingga bukti yang ada di persidangan dapat dipertanggungjawabkan kebenarannya di mata hokum; (2) Penulis menyarankan Majelis untuk dapat menyelesaikan Sengketa Pajak lebih cepat agar Wajib Pajak tidak terbebani sanksi administrasi apabila kurang bayar dan dapat menyelesaikan Sengketa Pajak lainnya agar tidak tertunda dan melebihi waktu yang ditentukan karena apabila melebihi waktu, putusan Pengadilan Pajak akan menerima seluruhnya permohonan banding Wajib Pajak walaupun kasus tersebut belum terselesaikan dan ini akan merugikan Negara; (3) menurut penulis sebaiknya jumlah Hakim dalam Pengadilan Pajak ditambah karena sudah semakin banyak Wajib Pajak yang mengajukan banding atas Sengketa Pajak yang dihadapi Wajib Pajak agar penyelesaian Sengketa Pajak tersebut dapat diselesaikan secara cepat, maksimal, dan tidak mengurangi kualitas Hakim di Pengadilan Pajak. 


\section{DAFTAR PUSTAKA}

Andriani, P. J. A. (2000). Pajak dan Pembangunan. Jakarta: UI Press.

Direktur Jenderal Pajak. (2000). Surat Edaran Direktur Jenderal Pajak Nomor SE-24/PJ.43/2000 tentang Penegasan tentang Pengertian Force Majeure Dalam Surat Edaran Nomor SE21/PJ.4/1995 Tentang Surat Keterangan Bebas (SKB) Pemotongan/Pemungutan PPh.

Ikatan Akuntan Indonesia. (2009). Modul pelatihan pajak brevet A \& B - Ikatan Akuntan Indonesia. Jakarta: Ikatan Akuntan Indonesia.

Ilyas, W. B., \& Burton, R. (2008). Hukum pajak (4th ed.). Jakarta: Salemba Empat.

Mardiasmo. (2008). Perpajakan. Yogyakarta: Andi.

Menteri Keuangan. (2007). Peraturan Menteri Keuangan Nomor:194/PMK.03/2007 tentang Tata Cara Pengajuan dan Penyelesaian Keberatan.

Oktavia, K., \& Setyawan, A. B. (2007). Penyelesaian kesalahan penafsiran atas pajak pertambahan nilai. Paper dipresentasikan pada Proceeding PESAT, Universitas Gunadarma.

Pardiat. (2008). Pemeriksaan pajak (2nd ed.). Jakarta: Mitra Wacana Media.

Republik Indonesia. (2007). Undang-Undang Republik Indonesia Nomor 28 Tahun 2007 Perubahan Ketiga Atas Undang-undang Nomor 6 Tahun 1983 tentang Ketentuan Umum dan Tata Cara Perpajakan. Jakarta: Sekretariat Negara. 